University of New Hampshire

University of New Hampshire Scholars' Repository

12-15-1995

\title{
A simple model to estimate atmospheric concentrations of aerosol chemical species based on snow core chemistry at Summit, Greenland
}

\author{
$\mathrm{M} \mathrm{H}$. Bergin \\ Carnegie Mellon University \\ C Davidson \\ Carnegie Mellon University \\ Jack E. Dibb \\ University of New Hampshire, jack.dibb@unh.edu \\ J L. Jaffrezo \\ Domaine Universitaire, Grenoble, Franc \\ H D. Kuhns \\ Carnegie Mellon University \\ See next page for additional authors \\ Follow this and additional works at: https://scholars.unh.edu/earthsci_facpub \\ Part of the Atmospheric Sciences Commons
}

\section{Recommended Citation}

M. H. Bergin, C. I. Davidson, J. E. Dibb, J. L. Jaffrezo, H. D. Kuhns, and S. N. Pandis, "A simple model to estimate atmospheric concentrations of aerosol chemical species based on snow core chemistry at summit, Greenland," Geophysical Research Letters, vol. 22, no. 24, pp. 3517-3520, Dec. 1995.

This Article is brought to you for free and open access by the Earth Sciences at University of New Hampshire Scholars' Repository. It has been accepted for inclusion in Earth Sciences Scholarship by an authorized administrator of University of New Hampshire Scholars' Repository. For more information, please contact Scholarly.Communication@unh.edu. 


\section{Authors}

M H. Bergin, C Davidson, Jack E. Dibb, J L. Jaffrezo, H D. Kuhns, and S N. Pandis 


\title{
A simple model to estimate atmospheric concentrations of aerosol chemical species based on snow core chemistry at Summit, Greenland
}

\author{
M.H. Bergin ${ }^{1,2}$, C.I. Davidson ${ }^{1,3}$, J.E. Dibb ${ }^{4}$, J.L. Jaffrezo ${ }^{5}$, H.D. Kuhns ${ }^{1}$, and S.N. Pandis ${ }^{6}$
}

Abstract. A simple model is presented to estimate atmospheric concentrations of chemical species that exist primarily as aerosols based on snow core/ice core chemistry at Summit, Greenland. The model considers the processes of snow, fog, and dry deposition. The deposition parameters for each of the processes are estimated for $\mathrm{SO}_{4}{ }^{2-}$ and $\mathrm{Ca}^{2+}$ and are based on experiments conducted during the 1993 and 1994 summer field seasons. The seasonal mean atmospheric concentrations are estimated based on the deposition parameters and snow cores obtained during the field seasons. The ratios of the estimated seasonal mean airborne concentration divided by the measured mean concentration $\left(\overline{\mathrm{C}}_{\mathrm{a}, \mathrm{est}} / \overline{\mathrm{C}}_{\mathrm{a}, \text { meas }}\right)$ for $\mathrm{SO}_{4}{ }^{2-}$ over the 1993 and 1994 field seasons are 0.85 and 0.95 , respectively. The $\overline{\mathrm{C}}_{\mathrm{a}, \mathrm{eat}} / \overline{\mathrm{C}}_{\mathrm{a}, \text { meas }}$ ratios for $\mathrm{Ca}^{2+}$ are 0.45 and 0.90 for the 1993 and 1994 field seasons. The uncertainties in the estimated atmospheric concentrations range from $30 \%$ to $40 \%$ and are due to variability in the input parameters. The model estimates the seasonal mean atmospheric $\mathrm{SO}_{4}^{2-}$ and $\mathrm{Ca}^{2+}$ concentrations to within $15 \%$ and $55 \%$, respectively. Although the model is not directly applied to ice cores, the application of the model to ice core chemical signals is briefly discussed.

\section{Introduction}

The recently retrieved ice cores at Summit, Greenland are potentially the most valuable records of past environmental conditions available. The chemical and physical properties in ice cores clearly reflect past climatic conditions (Delmas and Legrand, 1989; Mayewski et al., 1994). Currently, quantitative estimates of past atmospheric concentrations of chemical species based on ice core chemistry are unavailable due to a lack of understanding of the processes that transfer atmospheric chemical species to the surface snow.

The main processes that deposit chemical species to the snow surface at Summit are snow, fog and dry deposition (Bergin et al, 1994; 1995a,b). Although snow deposition is the dominant process during the summer, it has been shown that deposition of chemical species with fog may contribute as much as one third to the summer chemical inventories of various chemical species and

\footnotetext{
'Department of Civil and Environmental Engineering, Carmegie Mellon University, Pittsburgh, Pennsylvania.

${ }^{2}$ Now at Climate Monitoring and Diagnostics Laboratory, National Oceanic and Atmospheric Administration, Boulder, Colorado.

'Department of Civil and Environmental Engineering and Engineering and Public Policy, Carnegie Mellon University, Pittsburgh, Pennsylvania.

Institute for the Study of Earth, Oceans, and Spece, University of New Hampshire, Durham.

'Laboratoire de Glaciologic et Góphysique de l'Environnement du CRNS, Saint Martin d'Héres, France.

Department of Chemical Engincering and Engincering and Public Policy, Carnegie Mellon University, Pittsburgh, Pennsylvania.
}

\section{Copyright 1995 by the American Geophysical Union.}

Paper number 95GL03196

0094-8534/95/95GL-03196\$03.00 that dry deposition is also significant (Bergin et al., 1995a, b). These results suggest that all of the deposition processes must be considered when developing relationships between air chemistry and snow/ice chemistry.

In this paper, we present a model for predicting airborne chemical concentrations based on chemical signals in snow. The model considers the processes of snow, fog, and dry deposition.

\section{Model}

The inventory of an aerosol chemical species, $I_{c}$ (mass of a chemical species/area), in a snow or ice core can be written as:

$$
I_{c}=\int_{0}^{\tau}\left(J_{d r y}+J_{\text {snow }}+J_{\text {fog }}\right) d t
$$

where $J_{d y y}, J_{\text {snow }}$, and $J_{\text {fog }}$ are the chemical species fluxes (ng/m $\mathrm{m}^{2} \mathrm{~s}$ ) due to dry, snow and fog deposition, and $\tau$ is the time period over which the chemical fluxes occur. Equation 1 assumes that the drifting of snow has a negligible effect on the inventory of aerosol chemical species over the time period $\tau$. Assuming dry and fog deposition fluxes to snow as described by Bergin et al. (1994) and a snow deposition flux as presented by Davidson et al. (1991), equation 1 can be written as:

$$
I_{c}=\bar{C}_{a}\left(V_{d} \tau\right)+\bar{C}_{a}\left(\frac{I_{\text {snow }} W}{P_{\text {air }}}\right)+\bar{C}_{a}\left(\operatorname{nhR}\left(1-\exp \left(\frac{-V_{s} t_{f}}{h}\right)\right)\right)
$$

$\overline{\mathrm{C}}_{\mathrm{a}}$ is the mean atmospheric concentration $\left(\mathrm{ng} / \mathrm{m}^{3}\right)$ over the time period $\tau, V_{d}$ is the aerosol dry deposition velocity $(\mathrm{m} / \mathrm{s}), I_{\text {snow }}$ is the snow inventory $\left(g_{\text {mow }} / \mathrm{m}^{2}\right), W_{\text {mem }}$ is the snow mass

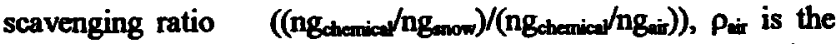
density of air $\left(\mathrm{g} / \mathrm{m}^{3}\right), \mathrm{n}$ is the number of fog events during the time period, $R$ is the fraction of mass incorporated into fog droplets, $V$, is the settling velocity of the fog droplets $(\mathrm{m} / \mathrm{s}), \mathrm{t}_{\mathrm{f}}$ is the typical duration of a fog event (s), and $h$ is the fog height $(\mathrm{m})$. It is worthwhile to point out we assume the atmospheric concentration impacting each atmospheric process is the mean concentration during the time period $\left(\overline{\mathrm{C}}_{\mathrm{n}}\right)$. For this assumption to be valid it is necessary to assume that the atmospheric concentrations during the snow and fog events are similar to the mean atmospheric concentration over the time period $\tau$. Since resolving discrete events in ice cores is not possible, this assumption is necessary. Equation 2 can be simplified and written as:

$$
I_{c}=\bar{C}_{\mathbf{a}}\left(k_{\text {dry }}+k_{\text {snow }}+k_{\text {fog }}\right)
$$

where $\mathbf{k}_{\text {dry }} \mathbf{k}_{\text {mow, }}$ and $\mathbf{k}_{\text {fog }}$ are the deposition factors (m).

In this paper Equation 3 will be used to estimate $\overline{\mathrm{c}}_{2}$ for $\mathrm{SO}_{4}{ }^{2-}$ and $\mathrm{Ca}^{2+}$ aerosol during the 1993 and 1994 summer field seasons.

\section{Experimental Methods}

\section{Atmospheric Sampling}

Daily aerosol samples were collected on Teflon Zefluor filters and analyzed for major anions and cations by Ion Chromatography (IC). During the 1993 field season samples were collected at the $28 \mathrm{~km}$ SSW of the GISP2 main camp. Sampling took place from 25-May to 13-July. During the 1994 field season 
sampling took place $10 \mathrm{~km}$ SSW of the main camp. Sampling during the 1994 season was conducted from 10-May to 9-July.

A 12- stage impactor was used to sample aerosol mass size distributions (Maenhaut et al., 1995). Several impactor samples were analyzed for major anions and cations by IC as well as for additional elements by proton-induced X Ray emission (PIXE).

\section{Snow Cores}

At the beginning of each field season, string markers were laid across the surface snow at the atmospheric camps. At the end of each field season snow cores were excavated from the surface down to the string markers. The samples were collected at $2 \mathrm{~cm}$ vertical intervals using a clean Plexiglas tool. Samples were weighed and analyzed for major anions and cations by IC. For each $2 \mathrm{~cm}$ layer, the inventory of a chemical species was determined by multiplying the snow inventory by the chemical concentration. The seasonal chemical inventories were determined by adding the sequence of samples from the surface snow to the string marker. The snow cores obtained for the two field seasons represent snow accumulation from 28-May to 14-July, 1993 and 2-May to 30-July, 1994.

\section{Application of the Model}

\section{Model Input Values}

Table 1 shows the measured snow inventory and chemical inventories for the $\mathrm{Ca}^{2+}$ and $\mathrm{SO}_{4}{ }^{2-}$ snow cores obtained during the 1993 and 1994 field seasons. It is worthwhile to point out that the snow inventories for the 1993 and 1994 field seasons are similar (within 20\%) to mean inventories measured at 100 stakes placed in a $100 \mathrm{~m} \times 100 \mathrm{~m}$ grid for several previous summer field seasons at Summit (Bergin et al., 1995a). In some cases the seasonal accumulations measured at grid points at Summit yield negative values. This suggests that snow from a given season may not always be represented in an annual snow core (i.e. an ice core sample). The snow cores obtained for this study represent mean snow accumulations over the 1993 and 1994 field seasons, and we therefore assume that these snow cores contain a snow deposition record that represents the majority of the snow events occurring throughout the field seascons. Table 2 shows the dry deposition velocities for both $\mathrm{SO}_{4}{ }_{4}^{2-}$ and $\mathrm{Ca}^{2+}$ which are used to estimate $k_{d y}$. The dry deposition velocities are based on impactor mass size distributions obtained during the 1993 season (Bergin et al., 1994b). Table 2 also shows the scavenging ratios which are used along with $I_{\text {now }}$ in Table 1 to estimate $k_{\text {mowr }}$. The scavenging ratios are estimated from several fresh snow samples collected during the 1993 field season (Davidson et al., 1995) and agree with the values reported for $\mathrm{SO}_{4}{ }^{2-}$ and several coarse mode aerosols from Dye3, Greenland (Davidson et al., 1985).

In order to estimate $\bar{c}_{a}$ it is also necessary to measure or estimate the parameters that influence $k_{f o g}$ which are $n, R, V_{z}, t_{6}$ and $h$. There were 19 fog events during the 1993 field season and 31 fog events during the 1994 field season. Several impactor samples obtained before and during fog events for the 1993 field season suggest that $\mathrm{R}$ for $\mathrm{SO}_{4}{ }^{2-}$ is $0.7+/-0.15$ (Bergin et al., 1995b). Since $\mathrm{Ca}^{2+}$ is a coarse mode aerosol we assume that all of these particles are activated as fog condensation nuclei and therefore $R$ is 1 . We assume that the settling velocity of fog

TABLE 1. Measured snow $\left(I_{\text {snow }}\right)$ and

chemical $\left(\mathrm{I}_{\mathrm{C}}\right)$ inventories

\begin{tabular}{ccccc}
\hline $\begin{array}{c}\text { Field } \\
\text { Season }\end{array}$ & Dale & $\begin{array}{c}I_{\text {gnow }} \\
\left(\mathrm{g} / \mathrm{cm}^{2}\right)\end{array}$ & $\begin{array}{c}\mathrm{I}_{\mathrm{Ca}^{2+}} \\
\left(\mathrm{ng} / \mathrm{cm}^{2}\right)\end{array}$ & $\begin{array}{c}I_{\mathrm{SO}_{4}{ }^{2}} \\
\left(\mathrm{ng} / \mathrm{cm}^{2}\right)\end{array}$ \\
\hline 1993 & 28-May to 14-July & 4.1 & 42 & 390 \\
1994 & 2-May to 30-July & 3.6 & 44 & 370 \\
\hline
\end{tabular}

TABLE 2. Measured dry deposition velocities $\left(V_{d}\right)$ and snow mass scavenging ratios ( $W_{\text {mass }}$ )

\begin{tabular}{ccc}
\hline Species & $\mathrm{V}_{\mathrm{d}}(\mathrm{cm} / \mathrm{s})^{1}$ & $\mathrm{~W}_{\text {mass }}{ }^{2}$ \\
\hline $\mathrm{SO}_{4}{ }^{2}$ & $0.021(2.0)$ & $220(1.7)$ \\
$\mathrm{Ca}^{2+}$ & $0.110(1.2)$ & $840(1.6)$ \\
\hline
\end{tabular}

Note: Reported values represent the geometric mean with the geomtric standard deviation in paranthesis

'Bergin ef al., 1995b; 'Davidson et al., 1995

droplets is $1.0 \mathrm{~cm} / \mathrm{s}+/-0.2 \mathrm{~cm} / \mathrm{s}$. This corresponds to fog droplet diameters of 15 um-20 um and is based on measurements made by Borys et al. (1992) for several fog events during the 1991 field season. Observation of several fog events during past summer field seasons indicates that the average duration of an event is generally 7 hours with a standard deviation of 2 hours. Although the fog heights have not been directly measured, modeling of radiation fogs at Summit suggests that the fog heights are typically $100 \mathrm{~m}-200 \mathrm{~m}$ (Bergin, 1995c). Therefore, we assume that the average height of a radiation fog during the summer at Summit is $150 \mathrm{~m}$ with a standard deviation of $50 \mathrm{~m}$.

\section{Model Result:}

Figures 1 and 2 show $\mathrm{k}$ values for both $\mathrm{SO}_{4}^{2-}$ and $\mathrm{Ca}^{2+}$ for the 1993 field seasons which are estimated using values in Tables 1 and 2 and using parameters for fog discussed in the previous section. The $k$ values are estimated using Monte Carlo simulations. The parameters used to estimate the $k$ values are converted to lognormal parameters for the simulations. Figure 1 shows that for both seasons the $\mathrm{k}$ values for $\mathrm{SO}_{4}{ }^{2-}$ yield relative seasonal inventory contributions from snow, fog, and dry deposition of roughly $65 \%, 20 \%$, and $15 \%$, respectively. These results agree with the relative contributions from snow, fog, and dry deposition of $61 \%, 26 \%$, and $13 \%$, respectively, measured during the 1993 field season (Bergin et al., 1995b). It is worthwhile to point out that we assume $\mathrm{SO}_{2}$ does not contribute to the seasonal inventories through fog and dry deposition. Bergin et al. (1995c) suggest that in some cases $\mathrm{SO}_{2}$ concentrations may be great enough to contribute significantly to the deposition of $\mathrm{SO}_{4}{ }^{2-}$ with fog. Estimates of $\mathrm{SO}_{2}$ concentrations based on $\mathrm{S}(\mathrm{VI})$ in mist chamber samples suggest that the molar ratio of atmospheric $\mathrm{SO}_{2}$ to aerosol $\mathrm{SO}_{4}^{2-}$ is typically 0.3 or less (Dibb et al., 1994). Due to our current lack of knowledge of typical $\mathrm{SO}_{2}$ concentrations at Summit, as well as in our lack of understanding of the surface snow properties that affect the dry deposition of soluble gases, we

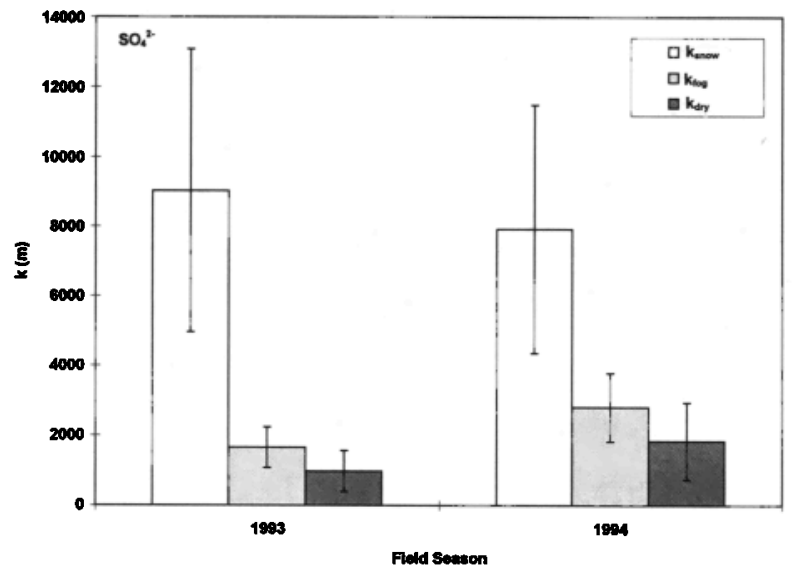

Figure 1. Estimates of $k_{\text {mon }}, k_{\text {fog }}$ and $k_{d y}$ for $\mathrm{SO}_{4}{ }^{2-}$ for the 1993 and 1994 field seasons 


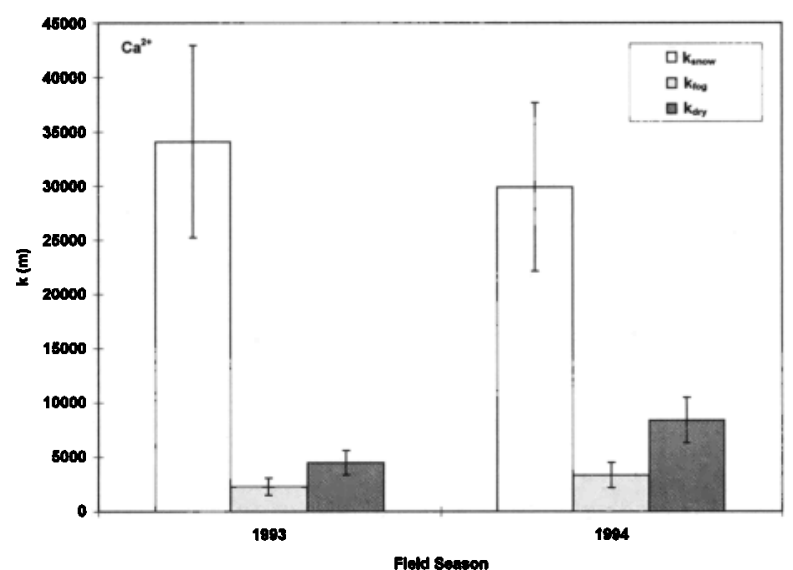

Figure 2. Estimates of $k_{\text {mom }} k_{608}$ and $k_{d y}$ for $\mathrm{Ca}^{2+}$ for the 1993 and 1994 field seasons

assume that aerosol $\mathrm{SO}_{4}{ }_{4}^{2-}$ is entirely responsible for the sulfate signal in surface snow. Figure 1 shows that there are typically uncertainties of $30 \%$ to $40 \%$ in each of the $\mathrm{k}$ values, which originate from the variability in the various parameters used to estimate the $k$ values.

Figure 2 shows the $\mathrm{k}$ values for $\mathrm{Ca}^{2+}$. The $\mathrm{k}$ values suggest that the relative contributions to the seasonal $\mathrm{Ca}^{2+}$ inventory for snow, fog, and dry deposition are roughly $70 \%, 10 \%$, and $20 \%$, respectively. These results agree with the measured contributions from snow, fog, and dry deposition for the 1993 field season of $63 \%, 13 \%$, and $18 \%$, respectively (Bergin et al., 1995b).

Figure 3 shows the ratios of the mean seasonal atmospheric concentrations, estimated by equation 3 , divided by the measured seasonal mean concentrations ( $\overline{\mathrm{C}}_{2, \text { eat }} / \overline{\mathrm{C}}_{\mathrm{a}, \mathrm{meas}}$ ) for both $\mathrm{SO}_{4}{ }^{2-}$ and $\mathrm{Ca}^{2+}$. The error bars in Figure 3 represent uncertainties in the estimated atmospheric concentrations associated with uncertainties in the $k$ values shown in Figures 1 and 2. For $\mathrm{SO}_{4}{ }^{2-}$

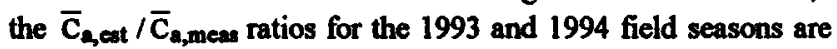
0.85 and 0.95 , respectively. The uncertainty in the estimation of the mean atmospheric $\mathrm{SO}_{4}^{2-}$ concentration is roughly $35 \%$ and is due primarily to the variability associated with $\mathrm{W}_{\text {mown }}$. The $\bar{C}_{a, c a t} / \bar{C}_{a, m e a s}$ ratios for $\mathrm{Ca}^{2+}$ over the 1993 and 1994 field seasons are 0.45 , and 0.90 , respectively. The ratio for the 1993 field season may be low since the mean atmospheric concentration is dominated by a 10 day period having no snow events (Bergin et al., 1995b). Since snow deposition is the dominant process for $\mathrm{Ca}^{2+}$ the resultant effect may be that the extremely high $\mathrm{Ca}^{2+}$ atmospheric concentrations are not archived in the snow core. Another possible explanation for the low

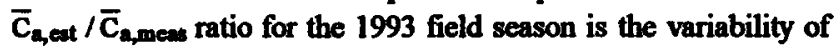
surface snow $\mathrm{Ca}^{2+}$ concentrations. The coefficient of variation of the $\mathrm{Ca}^{2+}$ concentration for replicate surface snow samples at Summit is typically 0.3 while the coefficient of variation for $\mathrm{SO}_{4}{ }^{2-}$ is generally 0.1 or less (Dibb, 1995). It is possible that the variability in surface snow $\mathrm{Ca}^{2+}$ concentrations accounts for the $55 \%$ underestimation of the 1993 field season atmospheric concentration. Since surface snow variability is much greater for $\mathrm{Ca}^{2+}$ the core obtained during the 1993 field season may represent a lower limit inventory. In contrast, we expect that there is not a great deal of variability in the snow core $\mathrm{SO}_{4}{ }^{2-}$ inventories based on the smaller variability in surface snow $\mathrm{SO}_{4}{ }^{2-}$ concentrations. In general, Figure 3 shows that modeled mean atmospheric concentration estimates agree with measured $\mathrm{SO}_{4}{ }_{4}^{2-}$ concentrations and are within $55 \%$ of the measured $\mathrm{Ca}^{2+}$ concentrations.

\section{Application of the Model to Ice Cores}

The model highlights the key parameters needed to estimate past atmospheric concentrations of chemical species that exist primarily as aerosols based on snow/ice core samples. The annual chemistry and snow accumulation have been determined for the ice cores obtained at Summit (Alley et al., 1993; Mayewski at al., 1994). This supplies annual and in some cases seasonal values of $I_{c}$ and $I_{\text {mow. }}$. Perhaps the greatest problem in applying the model to ice core interpretation is making realistic estimates of the parameters that are used to determine $k_{d y}, k_{\text {mow, }}$ and $k_{80 g}$ for past atmospheres.

The dry deposition velocity to snow is sensitive to the aerosol size distribution in the atmospheric boundary layer (lbrahim et al., 1982). It has also been shown that the snow mass scavenging efficiency of ice crystals is sensitive to the aerosol mass size distribution (Miller and Wang, 1989). Due to changes in source regions, cloud processing, and transport times over the past 250,000 years it is likely that the aerosol mass mean diameter has fluctuated. Indeed, it has been shown that the size distribution of insoluble particles has a seasonal pattern in South Greenland snow associated with these processes (Steffenson, 1985). Furthermore, the mass mean diameter of insoluble particles in ice core samples significantly increased during the Younger Dryas period, showing that changes in climatic conditions impact aerosol particle sizes reaching Greenland (Zielinski, personal communication). These results suggest that it may be necessary to consider changes in the dry deposition velocities and snow mass scavenging ratios based on changes in the aerosol mass size distribution during past climatic conditions when using equation 3 to interpret ice core data.

Estimating $\mathbf{k}_{\text {fog }}$ for past climatic conditions is perhaps the most problematic of the issues concerning the estimate of past atmospheric concentrations based on ice core signals. Although observations from Dye 3, Greenland show that fogs occur throughout the year (Bergin et al., 1994), the number of fog events that occur during the winter months at Summit is currently unknown. Therefore, it is difficult to determine the extent to which fogs at Summit affect annual chemical signals during present conditions. If fogs have significantly contributed to past annual chemical signals it is important to have accurate estimates of $k_{\text {fog }}$ to determine past atmospheric concentrations. Currently, there are no known ice core properties that can be used to infer the parameters $\left(n, R, V_{s}, t_{6}\right.$ and $\left.h\right)$ that affect fog deposition.

Overall, it is necessary to estimate the deposition parameters for past atmospheres in order to determine past atmospheric

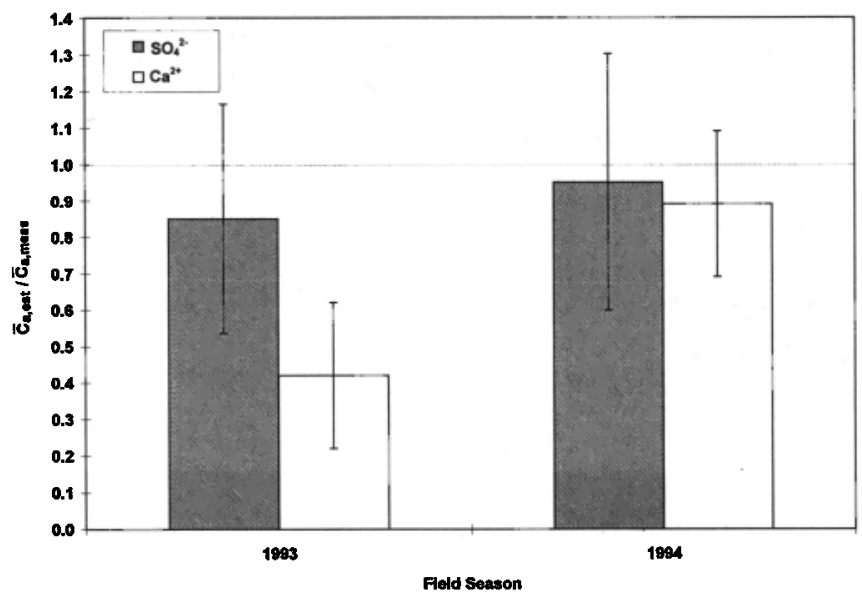

Figure 3. $\overline{\mathrm{C}}_{\mathrm{a}, \mathrm{ent}} / \overline{\mathrm{C}}_{\mathrm{a}, \mathrm{mene}}$ for $\mathrm{SO}_{4}{ }^{2-}$ and $\mathrm{Ca}^{2+}$ for the 1993 and 1994 field seasons 
concentrations of aerosols based on ice core chemical signals. It is possible that insoluble particle size distributions may be used to infer changes in both the snow mass scavenging ratio and dry deposition velocity. It is important to consider all of the deposition processes since during periods of relatively high snow accumulation snow deposition is likely the dominant deposition process while during colder periods with lower accumulation (i.e. Younger Dryas) dry deposition and possibly fog deposition are the processes which dominate aerosol deposition.

\section{Conclusions}

In this paper a model is developed to estimate atmospheric concentrations of aerosol chemical species based on snow corefice core chemistry. The model considers the processes of snow, fog, and dry deposition, and is applied to snow cores obtained during the 1993 and 1994 summer field seasons at Summit, Greenland.

The ratio of the modeled to measured mean atmospheric aerosol concentrations $\left(\bar{C}_{2, c u t} / \bar{C}_{a, m e m e}\right)$ of $\mathrm{SO}_{4}{ }^{2-}$ for the 1993 and 1994 summer field seasons are 0.85 and 0.95 , respectively. $\overline{\mathrm{C}}_{\mathrm{a}, \mathrm{eat}} / \overline{\mathrm{C}}_{\mathrm{a}, \mathrm{mean}}$ for $\mathrm{Ca}^{2+}$ are 0.45 and 0.90 for the 1993 and 1994 field seasons. The ratio for the 1993 field season may be low since the measured mean atmospheric concentration is dominated by a 10 day period having no snow events. For all of the estimates of $\bar{C}_{a, \text { ent }} / \overline{\mathrm{C}}_{\mathrm{a}, \text { meas }}$ the uncertainty is from $30 \%$ to $40 \%$ and is due to variability in the parameters used to estimate $\mathbf{k}_{\mathbf{d y}}, \mathbf{k}_{\text {enow, }}$ and $\mathbf{k}_{\text {fog }}$. In general, the modeled mean atmospheric concentration estimates agree with measured $\mathrm{SO}_{4}{ }^{2-}$ concentrations and are within $55 \%$ of the measured $\mathrm{Ca}^{2+}$ concentrations.

The model identifies important parameters needed to estimate atmospheric concentrations of aerosol chemical species based on snow corefice core chemistry. Parameters such as the dry deposition velocity, $V_{d}$, and the snow mass scavenging ratio, $W_{\text {mass }}$ are sensitive to changes in the aerosol mass size distribution. It is probable that the aerosol size distributions have significantly changed over glacial and interglacial periods due changes in sources, cloud processing, and transport times. This suggests that the effects of changing climatic conditions on $V_{d}$

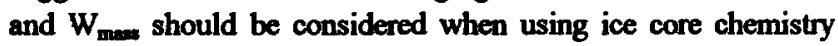
data to estimate atmospheric concentrations. Shifts in insoluble particle sizes toward larger diameters might be used to infer increases in $V_{d}$ and $W_{\text {masus }}$, although further research is needed to quantify these increases. Also, it is important to determine if fog significantly contributes to the annual inventories throughout various climatic conditions.

Acknowledgments. We would like to thank Sallie Whitlow for the IC analyses of snow core samples. We also thank GISP2 SMO, PICO, as well as the Danish Research commission for granting permission to study in Greenland. This work was supported by NSF grants DPP-9123082, OPP9321642, and OPP-9423410.

\section{References}

Alley, R.B., et al., Abrupt increase in Groenland snow accumulation at the end of the Younger Dryas event, Nature, 362, 527-529, 1993.

Bergin, M.H., J.L. Jaffrezo, C.I. Davidson, R. Caldow, and J.E. Dibb, Fluxes of chemical Species to the Greenland Ice Sheet at Summit by fog and dry deposition, Geochem. Casmochtm Acta, 58, 3207-3215, 1994.
Bergin, M.H., C.I. Davidson, J.L. Jaffrezo, J.E. Dibb, R. Hillamo, H.D. Kuhns, and $T$. Makela The contributions of wet, fog, and dry deposition to the summer flux of $\mathrm{SO}_{4}{ }^{2}$ at Summit, Greenland, In: "Ice Core Studies of Global Biogeochemical Cycles', R. Delmas (ed), NATO-ASI Series; Vol. 30, 121-138, Springer Verlag, Berlin, 1995a.

Bergin M.H. J.-L. Jaffrezo, C.I. Davidson, J.E. Dibb, S.N. Pandis, R. Hillamo, W. Maenhaut, H.D. Kuhns, and T. Makela, The contributions of snow, fog. and dry deposition to the summer fluxes of major anions and cations at Summit, Greenland, J. Geophys. Res., in press, 1995b.

Bergin, M.H., S.N. Pandis, C.I. Davidson, J.-L. Jaffrezo, J.E. Dibb, A.G. Russell, and H.D. Kuhns, Modeling of the processing and removal of trace gas and aerosol species by Arctic radiation fogs, Submitted to $J$. Geophys. Res. $1995 \mathrm{c}$.

Borys R.D. D. Del Vecchio, J.L. Jaffrezo, J.E. Dibb, and D.L. Mitchell, Field observations, measurements and preliminary results from a study of wot deposition processes influencing snow and ice chemistry at Summit, Greenland, In: 'Precipilation, Scavenging and Atmospheric Surface Exchange, S.E. Swchartz and W.G.N. Slinn (eds.), Hemisphere Publishing Corp., Vol. 3, pp.1693-1702, 1992.

Delmas, R.J., and M. Legrand, Long-term changes in the concentrations of major chemical compounds (soluble and insoluble) along deep, ice cores, In The Envirommental Record in Glaciers and Ice Sheets', H. Oeschger and C.C. Langway, Jr. (ed), Dahlem Workshop Report, Wiley and Sons, 1989.

Davidson, C.I., S. Santhanam, R.C. Fortman, and M.P. Olson, Atmospheric transport and deposition of trace elements to the Groenland Ice Sheet, Amos. Envinon., 19, 2065-2081, 1985.

Davidson, C.I., J.-L. Jaffrezo, and P. Mayewski, Arctic air pollution as reflected in snowpits and ice cores, in 'Pollution of the Arctic atmosphere', W.T. Sturges (ed), Elsevier Science Publishers, 1991.

Davidson, C.I., Bergin, M.H., Kuhns H.D., The Deposition of Particles and Gases to Ice Sheets, E. Wolfe (ed.), NATO-ASI series, March 1995 NATO workshop to be held in ltaly, Submitted January, 1995.

Dibb, J.E., Talbot R.W., and M.H. Bergin, Soluble acidic species at Summit Greenland, Geophys. Res. Leth. 21 (15), 1627-1630, 1994.

Dibb, J.E., Overview of Field data on the deposition of aerosol-associated species to the surface snow of polar glaciers (emphasizing recent work 'Processes of Chemical Exchange between the Atmasphere and Polar Snow', 1995 .

Ibrahim, M., L.A. Barrie, and F. Fanaki, An experimental investigation of the dry deposition of particles to snow, pine trees, and artificial collectors, Amos. Envinon. 17, 781-788, 1983.

Mayewski, P.A., et. al, Changes in atmospheric circulation and ocean ice cover over the North Atlantic during the last 41,000 years, Science, 263, 1747-1751, 1994.

Maeqhaut, W., Hillamo, R., Makela, T., Jaffrezo, J.L., Bergin, M.H., and C.I. Davidson, A new cascade impactor for aerosol sampling and subsequent PIXE analysis, Submitted to Instr. and Meth. in Phys. Res., 1995.

Miller, N.L., and P.K. Wang, Theoretical determination of the efficiency of aerosol particle collection by falling columnar ice crystals, J. Ammos. Sci., 46, 1656-1663, 1989.

Steffenson, J.P., Microparticles in snow from the South Greenland ice sheet, Tellus, 37B, 286-295, 1985.

M. H. Bergin, NOAA, e/E/CGI, 325 Broadway, Boulder, CO, 80303 (mbergin@cmdl.noaa.gov).

C. I. Davidson, Department of Civil and Environmental Engineering and Engineering and Public Policy and Director of the Environmental Institute, Carnegie Mellon University, PGH, PA, 15213 (cdow@andrew.cmu.edu).

H. D. Kuhns, Department of Civil and Environmental Engineering Carnegie Mellon University, PGH, PA, 15213 (hk26@andrew.cmu.edu).

J. E. Dibb, IEOS, University of New Hampshire, Durham, NH, 03824 (jed@unh.edu).

J.-L. Jaffrezo, LGGE du CRNS, Domaine Universitaire, Rue Moliere, BP96, 38402, Saint Martin d'Héres, France (jlj@glaciog.grenet.fr).

S. N. Pandis, Department of Chemical Engineering and Engineering and Public Policy, Camegic Mellon University, PGH, PA, 15213 (spyros@andrew.cmu.edu).

(Received June 20, 1995; revised September 1, 1995; accepted September 13, 1995) 